\title{
Pendampingan Sains Terapan untuk Meningkatkan Kompetensi Guru-Guru IPA dalam Pembelajaran Prakarya di Kabupaten Sijunjung
}

\section{Mentoring Activities of Applied Science to Improve the Competence of Natural Science Teachers in Prakarya Learning in Sijunjung Regency}

\author{
${ }^{1}$ Renol Afrizon, ${ }^{1}$ Hidayati, ${ }^{2}$ Relsas Yogica \\ ${ }_{1}^{1}$ Jurusan Fisika, Fakultas Matematika dan Ilmu Pengetahuan Alam, Universitas Negeri \\ Padang, Padang \\ ${ }^{2}$ Jurusan Biologi, Fakultas Matematika dan Ilmu Pengetahuan Alam, Universitas Negeri \\ Padang, Padang
}

Korespondensi: Renol Afrizon, afrizon@fmipa.unp.ac.id

Naskah Diterima: 17 September 2019. Disetujui: 22 Januari 2020. Disetujui Publikasi: 27 Januari 2020

\begin{abstract}
Junior high school natural science teachers in Sijunjung Regency are still not optimal in teaching of prakarya. This is due to the lack of application of natural science in prakarya learning. Prakarya subjects have four material aspects, namely: crafts, engineering, cultivation, and processing. The material aspect of crafts is more dominantly taught by science teachers in prakarya subjects even though this material aspect is more appropriate to be taught by arts / culture teachers. In addition, there are still very few natural science teachers who are able to compile prakarya student worksheets. The Community Partnership Program in the form of mentoring activities of applied natural science is very much needed by natural science teachers in learning prakarya. This activity aims to motivate and help natural science teachers to continue to improve their competencies, especially professional and pedagogical competencies. Community service activities in the form of mentoring activities use a method that consists of several stages. The initial stage is the orientation and discussion phase. The second stage is the preparation phase of the activity. The third stage is the mentoring stage 1 (in) with use the explanation, demonstration, and practice methods on mentoring activity. Data collection techniques with pre-test and post-test methods and analyzed using normalized gain. This activity has been carried out for 5 months from March to July 2019 at SMP Negeri 11 Sijunjung, Kamang Baru District, Sijunjung Regency, West Sumatra Province. The results of the activities showed that increasing the pedagogical competence of the Sijunjung district's natural science teachers in the prakarya learning was satisfactory. Meanwhile, increasing professional competence is quite satisfying. So, overall the improvement in the competence of Sijunjung district's natural science teachers in prakarya learning has been satisfactory.
\end{abstract}

Keywords: Community service, applied natural science, prakarya, professional, pedagogical

\begin{abstract}
Abstrak. Guru-guru IPA SMP di Kabupaten Sijunjung masih belum optimal dalam mengajarkan prakarya. Hal ini disebabkan karena masih kurangnya penerapan IPA dalam pembelajaran prakarya. Mata pelajaran prakarya memiliki empat aspek materi yaitu: kerajinan, rekayasa, budidaya, dan pengolahan. Aspek materi kerajinan lebih dominan diajarkan oleh guru IPA dalam mata pelajaran prakarya padahal aspek materi ini lebih tepat diajarkan oleh guru seni budaya/keterampilan. Selain itu, masih sedikitnya guru IPA yang mampu menyusun bahan ajar prakarya. Program Kemitraan Masyarakat dalam bentuk pendampingan implementasi sains terapan sangat diperlukan guru IPA dalam pembelajaran prakarya. Kegiatan ini bertujuan untuk memotivasi dan membantu guru-guru IPA untuk terus meningkatkan kompetensinya
\end{abstract}


terutama kompetensi professional dan pedagogik. Kegiatan pengabdian masyarakat dalam bentuk kegiatan pendampingan ini menggunakan metode yang terdiri dari beberapa tahapan. Tahap awal yang dilaksanakan adalah tahap orientasi dan diskusi. Tahap kedua berupa tahap persiapan kegiatan. Tahap ketiga adalah tahap pendampingan 1 (in) dengan menggunakan metode ceramah, demonstrasi, dan praktik pada kegiatan pendampingan. Teknik pengumpulan data dengan metode pre-test dan post-test dan dianalisis menggunakan gain ternormalisasi. Kegiatan ini telah dilaksanakan selama 5 bulan dari bulan Maret sampai dengan Juli 2019 di SMP Negeri 11 Sijunjung Kecamatan Kamang Baru, Kabupaten Sijunjung Provinsi Sumatera Barat. Hasil kegiatan menunjukkan bahwa peningkatan kompetensi pedagogik guru-guru IPA kabupaten Sijunjung dalam pembelajaran prakarya sudah memuaskan. Sedangkan, peningkatan kompetensi profesionalnya cukup memuaskan. Jadi, secara keseluruhan peningkatan kompetensi guru-guru IPA kabupaten Sijunjung dalam pembelajaran prakarya sudah memuaskan.

Kata Kunci: Pengabdian, sains terapan, prakarya, profesional, pedagogik

\section{Pendahuluan}

Prakarya terdiri atas empat aspek materi yaitu kerajinan, rekayasa, budidaya dan pengolahan. Aspek kerajinan memiliki ruang lingkup berupa kerja tangan yang hasilnya merupakan benda untuk memenuhi tuntutan kepuasan pandangan potensi lokal dan seni terapan (applied art), desain kekinian (modernisme dan post modernisme). Aspek rekayasa berkaitan dengan kemampuan merancang, merekonstruksi dan membuat produk yang bermanfaat dalam kehidupan seharihari dengan pendekatan pemecahan masalah sehingga dapat mengarahkan siswa berpikir kreatif, praktis, efektif, ketepatan dan hemat serta berpikir prediktif. Aspek budidaya terdiri atas budidaya tumbuhan dan hewan yang mencakup pembibitan, penanaman, pemanenan, penyimpanan, dan pengemasan serta distribusi untuk proses selanjutnya dengan tujuan agar siswa dapat berpikir sistematis berdasarkan potensi kearifan lokal. Aspek pengolahan berkaitan dengan perubahan bentuk dari bahan mentah menjadi produk olahan yang melibatkan proses-proses fisik, kimia, maupun mikrobiologis yang bertujuan untuk mengembangkan kepribadian (Kemendikbud, 2016). Jadi, 75\% dari keseluruhan aspek materi prakarya dapat dikaitkan dengan penerapan sains konsep sains/IPA dalam pembelajarannya.

Setiap satuan pendidikan wajib menyelenggarakan minimal 2 (dua) aspek dari 4 (empat) aspek materi prakarya yang disediakan (Kemendikbud, 2016). Pengorganisasian pelaksanaan pilihan dua aspek Prakarya tersebut tergantung pada aspek yang dipilih/disediakan oleh satuan pendidikan dan berdasarkan potensi daerah masing-masing. Mata pelajaran prakarya di kabupaten sijunjung terutama di kecamatan kamang baru tidak hanya diampu oleh guru yang memiliki latar belakang seni budaya dan keterampilan, tetapi juga diampu oleh guru-guru yang memiliki latar belakang pendidikan IPA. Hal ini dilaksanakan dalam rangka pemenuhan beban mengajar guru IPA di sekolah masing-masing.

Hasil analisis angket yang disebarkan oleh guru-guru IPA SMP Kabupaten Sijunjung menunjukkan bahwa pembelajaran prakarya di sekolahnya masingmasing masih memiliki beberapa kendala. Pertama, penerapan materi IPA dalam pembelajaran prakarya baru mencapai $55 \%$. Kedua, dari segi aspek materi yang diajarkan guru dalam mata pelajaran prakarya dimana 65\% guru mengajarkan aspek kerajinan, 15\% guru mengajarkan aspek rekayasa, 35\% guru mengajarkan aspek budidaya, dan 55\% guru mengajarkan aspek pengolahan. Hal ini menunjukkan bahwa aspek materi kerajinan lebih dominan diajarkan oleh guru IPA padahal aspek materi ini lebih tepat diajarkan oleh guru yang memiliki latar belakang pendidikan seni/budaya/keterampilan pada mata pelajaran prakarya. Ketiga, hanya 10\% guru-guru IPA yang mampu menyusun LKS mata pelajaran prakarya. Jadi, fakta yang ditemukan dilapangan menunjukkan kompetensi professional dan kompetensi pedagogik guru-guru IPA kabupaten Sijunjung dalam pembelajaran prakarya belum berperan secara optimal. 
Menyikapi kondisi tersebut, tim pengabdian merasa terpanggil untuk melaksanakan kegiatan yang dapat menyelesaikan masalah yang dihadapi oleh guru-guru IPA di kabupaten sijunjung dalam pembelajaran prakarya. Salah satu solusi yang diberikan berupa kegiatan pendampingan implementasi IPA/sains terapan dalam pembelajaran prakarya. Kegiatan ini difokuskan pada pemberian materi berupa model sains terapan yang sesuai dengan mata pelajaran prakarya untuk tingkat SMP/MTs dan potensi daerah serta penyusunan LKS mata pelajaran prakarya. Pengembangan pembelajaran prakarya harus diarahkan kepada teknologi tepat guna dengan mengganti bahan, bentuk serta keteknikan kepada pemenuhan prakarya family/home skill dan life skill dengan berbasis pada potensi/konteks lokal (kearifan lokal) setempat (Paresti dkk., 2013). Konstruksi atap rumah gadang terbuat dari ijuk tapi tetap bertahan dari masalah kebocoran dan terpaan angin (Afrizon dkk., 2017). Sains terapan ini sesuai dengan aspek rekayasa pada mata pelajaran prakarya Selain itu, hidroponik tanaman sayuran menggunakan sistem sumbu adalah teknologi hidroponik yang paling sederhana dan digunakan oleh kalangan pemula (Puspasari dkk., 2018). Hal ini sesuai dengan aspek budidaya pada mata pelajaran prakarya. Pembuatan biodiesel dari minyak jelantah juga cocok dengan aspek pengolahan pada mata pelajaran prakarya (Setiawati \& Edwar, 2012). Pelaksanaan kegiatan pendampingan sains terapan ini diharapkan mampu memotivasi guru untuk terus meningkatkan kompetensi professional dan pedagogik guru IPA dalam pembelajaran prakarya.

\section{Metode Pelaksanaan}

Tempat dan Waktu. Program Kemitraan Masyarakat (PKM) ini dilaksanakan di SMP Negeri 11 Sijunjung Kecamatan Kamang Baru, Kabupaten Sijunjung Provinsi Sumatera Barat selama 5 bulan dari bulan Maret sampai dengan Juli 2019. Tempat kegiatan berjarak $168 \mathrm{~km}$ dari Universitas Negeri Padang melalui perjalanan darat.

Khalayak Sasaran. Peserta kegiatan PKM ini adalah guru-guru MGMP IPA Jendela Dunia Kabupaten Sijunjung. Guru-guru IPA yang mengikuti kegiatan ini berjumlah 24 orang yang berasal dari 13 SMP dan MTs di kabupaten Sijunjung yang terdistribusi seperti pada Tabel 1 .

Tabel 1. Distribusi Peserta PKM

\begin{tabular}{crccc}
\hline \multirow{2}{*}{ No. } & \multirow{2}{*}{ Nama Sekolah } & Guru IPA & \multicolumn{2}{c}{ Keterangan } \\
\cline { 4 - 5 } & & 3 Orang & - & 3 \\
\hline 1. & SMPN 10 Sijunjung & 5 Orang & 3 & 2 \\
2. & SMPN 11 Sijunjung & 1 Orang & 1 & - \\
3. & SMPN 17 Sijunjung & 3 Orang & - & 3 \\
4. & SMPN 18 Sijunjung & 2 Orang & - & 2 \\
5. & SMPN 21 Sijunjung & 2 Orang & - & 2 \\
6. & SMPN 26 Sijunjung & 1 Orang & - & 1 \\
7. & SMPN 35 Sijunjung & 1 Orang & - & 1 \\
8. & SMPN 37 Sijunjung & 1 Orang & - & 1 \\
9. & SMPN 42 Sijunjung & 1 Orang & - & 1 \\
10. & SMPN 43 Sijunjung & 2 Orang & - & 2 \\
11. & SMPN 46 Sijunjung & 1 Orang & 1 & - \\
12. & SMPN 48 Sijunjung & 1 Orang & - & 1 \\
13. & MTsN 5 Sijunjung & 24 Orang & 5 Orang & 19 Orang \\
\hline \multicolumn{7}{c}{ Total }
\end{tabular}

Metode Pengabdian. Metode ipteks yang dilaksanakan pada kegiatan PKM adalah ceramah, diskusi, demonstrasi, dan praktik langsung pembuatan hidroponik dan biodiesel. Pembekalan materi berupa ceramah dilaksanakan pada hari pertama dan 
kedua kegiatan pendampingan. Kegiatan diskusi dilakukan berbarengan dengan ceramah oleh pemateri. Demonstrasi dilakukan pada saat pembuatan media tanam hidroponik, kreasi wadah, pembibitan, dan pembuatan larutan nutrisi yang terukur ppmnya. Selain itu, juga dilakukan pada pembuatan biodiesel dan minyak jelantah, pemurnian dan uji nyala biodiesel yang dibuat peserta. Selanjutnya, praktik langsung terkait dilakukan terkait pembuatan hidroponik dan biodiesel sesuai dengan yang didemonstrasikan oleh tim.

Indikator Keberhasilan. Terjadi peningkatan pengetahuan terkait kompetensi pedagogik dan professional guru IPA dalam pembelajaran prakarya melalui pendampingan sains terapan dengan nilai gain ternormalisasi <g> minimal berada pada interpretasi rendah atau mengalami peningkatan yang cukup memuaskan.

Metode Evaluasi. Evaluasi peningkatan pengetahuan terkait kompetensi guruguru IPA di kabupaten Sijunjung diukur menggunakan metode pre-test dan posttest (Rifa'i, dkk., 2017, 2018; Kudsiah, dkk., 2018). Lembar pre-test diberikan sebelum kegiatan pendampingan dilaksanakan dan Lembar post-test diberikan setelah kegiatan pendampingan pertama selesai. Peningkatan kompetensi dapat diketahui dengan analisis terhadap hasil pretes dan postes. Analisis dilakukan menggunakan rumus gain ternormalisasi oleh Hake (1998).

$$
\langle g\rangle=\frac{\%\langle G\rangle}{\%\langle G\rangle_{\max }}=\frac{\left(\%\left\langle S_{f}\right\rangle-\%\left\langle S_{i}\right\rangle\right)}{\left(100-\%\left\langle S_{i}\right\rangle\right)}
$$

dimana adalah rata-rata hasil posttest $\left\langle S_{f}\right\rangle$ dan rata-rata hasil pretest $\left\langle S_{i}\right\rangle$. Interpretasi dari skor Gain ternormalisasi dapat dilihat dari Tabel 2.

Tabel 2. Interpretasi nilai gain ternormalisasi

\begin{tabular}{cc}
\hline$\langle g\rangle$ & Interpretasi \\
$(\langle g\rangle)<0,3$ & Rendah \\
$0,3 \leq(\langle g\rangle)<0,7$ & Sedang \\
$(\langle g\rangle) \geq 0,7$ & Tinggi \\
\hline
\end{tabular}

\section{A. Persiapan}

\section{Hasil dan Pembahasan}

Sains terapan yang diberikan pada guru-guru IPA kabupaten Sijunjung yang mengajar mata pelajaran prakarya yaitu pembudidayaan sayuran setempat melalui hidroponik dan pembuatan biodiesel dari minyak jelantah. Persiapan kegiatan pembudidayaan hidroponik yang dilakukan berupa pembuatan model hidroponik dan pengujian model hidroponik mulai dari tanggal 6 April 2019 sampai dengan tanggal 10 juli 2019. Pembuatan dan pengujian biodiesel dengan bahan dasar minyak jelantah diujicobakan terlebih dahulu oleh tim sebelum ditransfer ke guruguru IPA di kabupaten Sijunjung. Selain persiapan sains terapan, tim juga memersiapkan kuisioner, pretest dan posttest, bahan ajar sebagai alat pengumpul data dan panduan berupa bahan ajar dalam kegiatan pendampingan. Selain itu, tim juga melakukan penyiapan pemateri dalam kegiatan pendampingan.

\section{B. Pembekalan Materi}

Sebelum diberikan materi pelatihan oleh 2 pemateri yang pakar di bidangnya. Tim memberikan soal pretest untuk mengetahui kondisi awal peserta pendampingan seperti terlihat pada Gambar 1 (a). Pembekalan materi pertama oleh bapak Drs. Mahrizal,M.Si mengenai hidroponik dan biodiesel seperti Gambar 1(b) dan dilanjutkan dengan pembekalan materi kedua oleh bapak Relsas Yogica, M.Pd berkenaan LKS dan prakarya pada Gambar 1 (c). Selanjutnya, tim memberikan model hidroponik kepada peserta yang ditempatkan di SMPN 11 Sijunjung seperti terlihat jelas pada Gambar 1 (d) dan beberapa perlengkapan hidroponik seperti 
nutrisi A dan B, rockwool, TDS, bibit kangkung dan bibit sawi. Kegiatan pembekalan ini dilaksanakan pada hari Sabtu tanggal 13 Juli 2019 di SMP Negeri 11 Sijunjung.

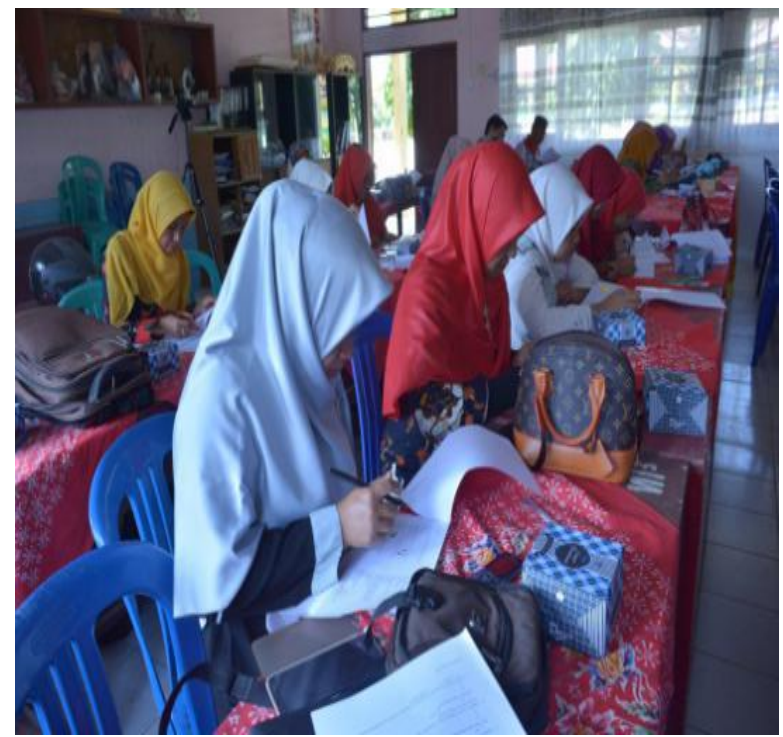

(a)

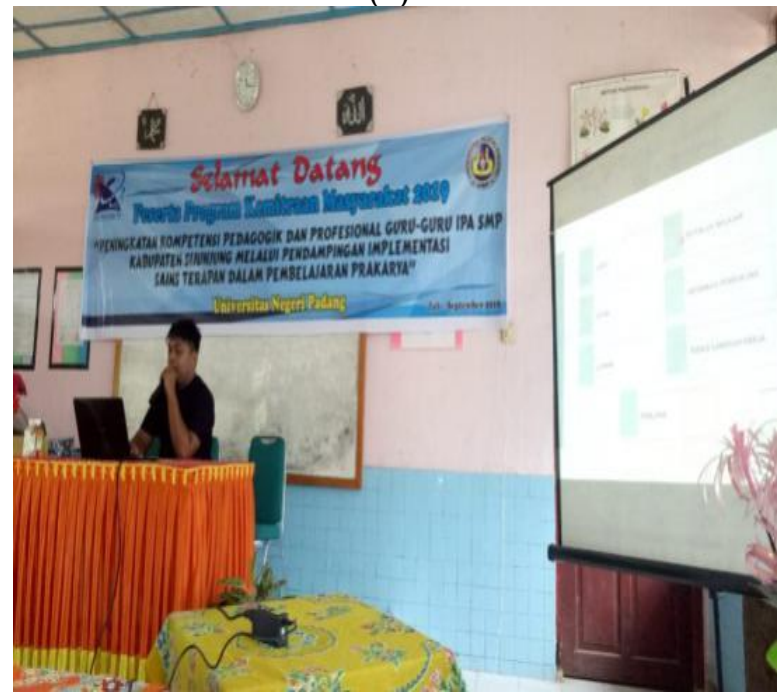

(c)

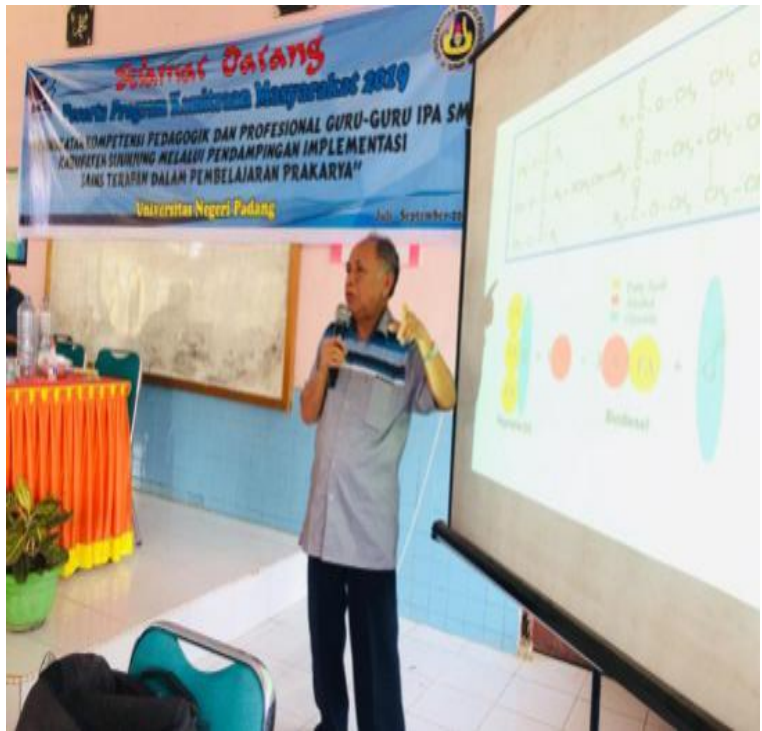

(b)

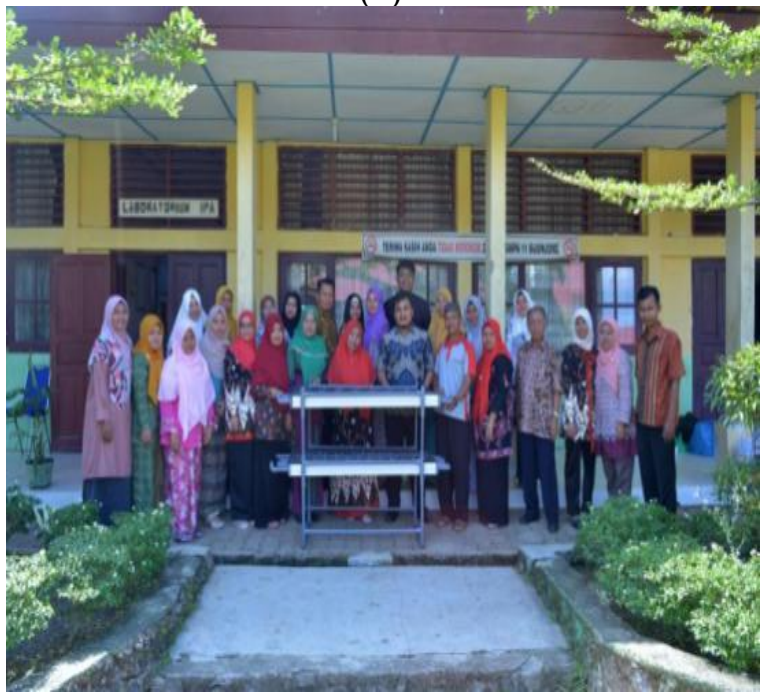

(d)

Gambar 1. Dokumentasi kegiatan pembekalan materi pendampingan sains terapan dalam pembelajaran prakarya (a) pretes, (b) pembekalan materi tentang hidroponik dan biodiesel, (c) pembekalan materi tentang prakarya dan lembar kerja siswa, (d) penyerahan model hidroponik kepada SMP Negeri 11 Sijunjung

\section{Demonstrasi dan Praktik Langsung}

Pelaksanaan kegiatan demontrasi dan praktik implementasi sains terapan pada tanggal 14 juli 2019 di SMPN 11 Sijunjung. Tim mendemonstrasikan pembuatan biodiesel seperti Gambar 2 (a). Peserta antusias dalam praktik pembuatan hingga pemurnian biodiesel dimana sebelumnya sudah dibagi dalam dua tim besar seperti gambar 2 (b). Selanjutnya, tim juga memberikan demonstrasi dan praktik langsung berkaitan pembuatan media tanam atau pemotongan rockwool seperti gambar 2 (c), pembuatan instalasi net pot, pembibitan, mengujicobakan pemakaian model hidroponik yang diberikan tim seperti gambar 2 (d), dan diakhiri dengan posttest. 


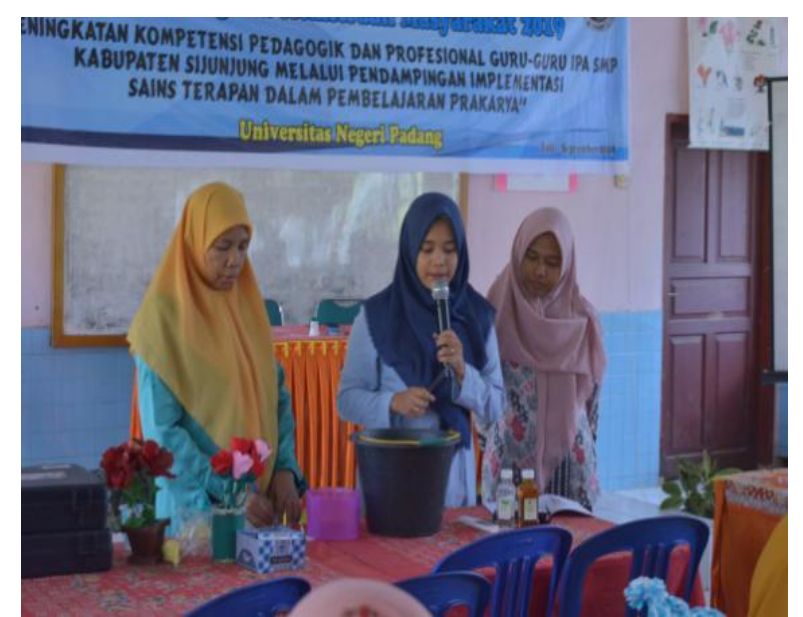

(a)

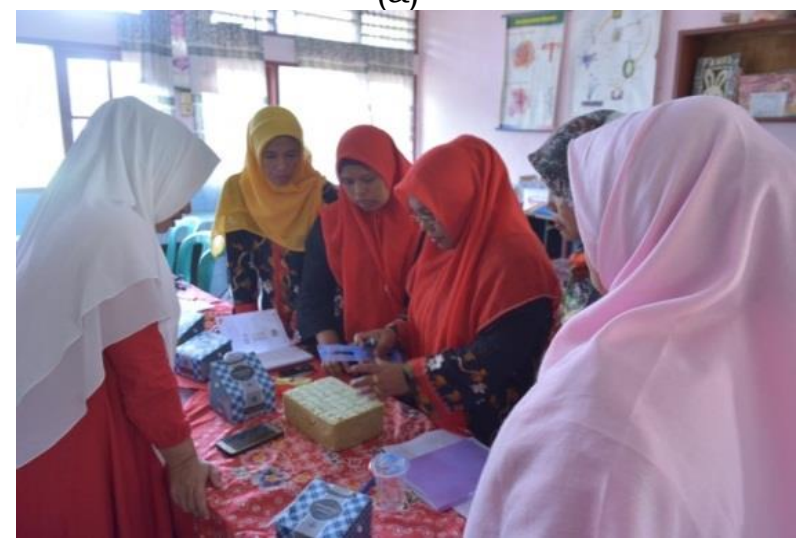

(c)

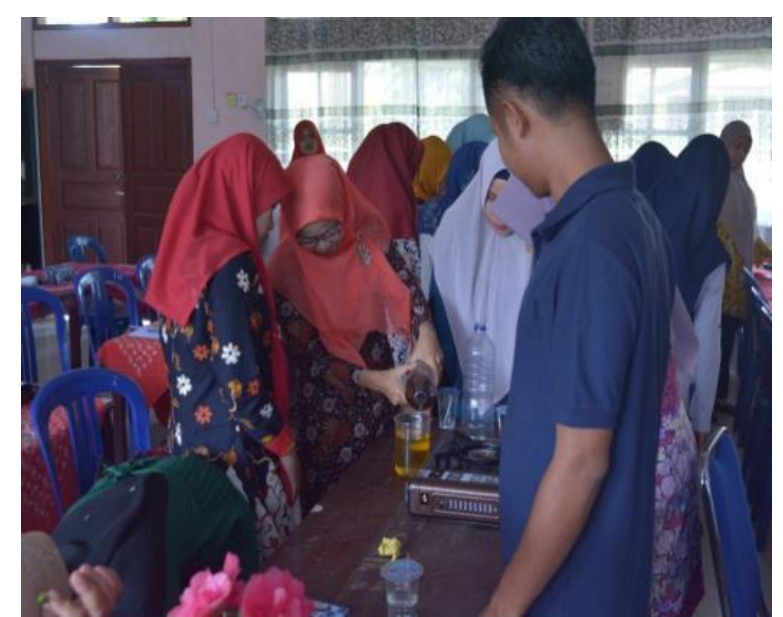

(b)

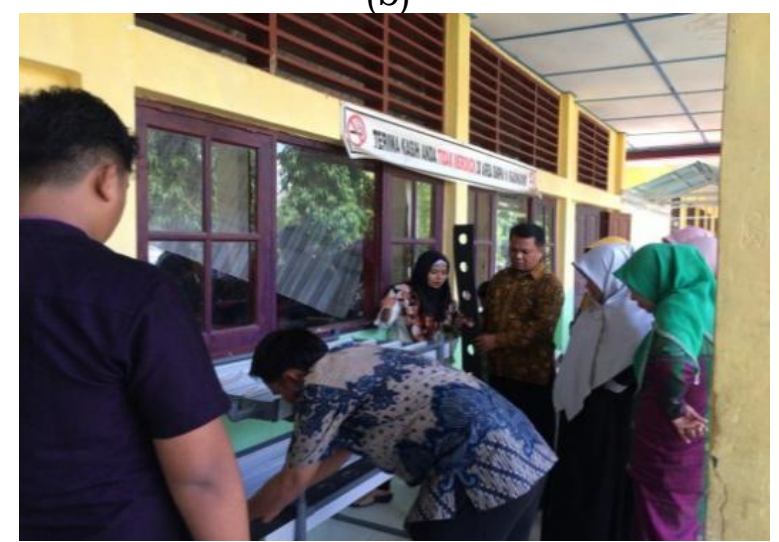

(d)

Gambar 2. Dokumentasi Kegiatan Demonstrasi dan praktik langsung sains terapan dalam pembelajaran prakarya: (a) demonstrasi pembuatan biodiesel oleh tim, (b) praktik pembuatan biodiesel, (c) praktik pemotongan media tanam hidroponik (rockwool), (d) demonstrasi penggunaan model hidroponik

\section{Keberhasilan Kegiatan}

Keberhasilan pelaksanaan kegiatan salah satunya dapat dilihat dari meningkatnya pengetahuan mitra. Peningkatan pengetahuan ditandai dengan meningkatnya kompetensi pedagogik dan kompetensi profesional guru-guru IPA. Hasil pengolahan data dari pretes dan postes yang telah dilakukan terlihat peningkatan kompetensi guru-guru IPA seperti pada gambar 3.

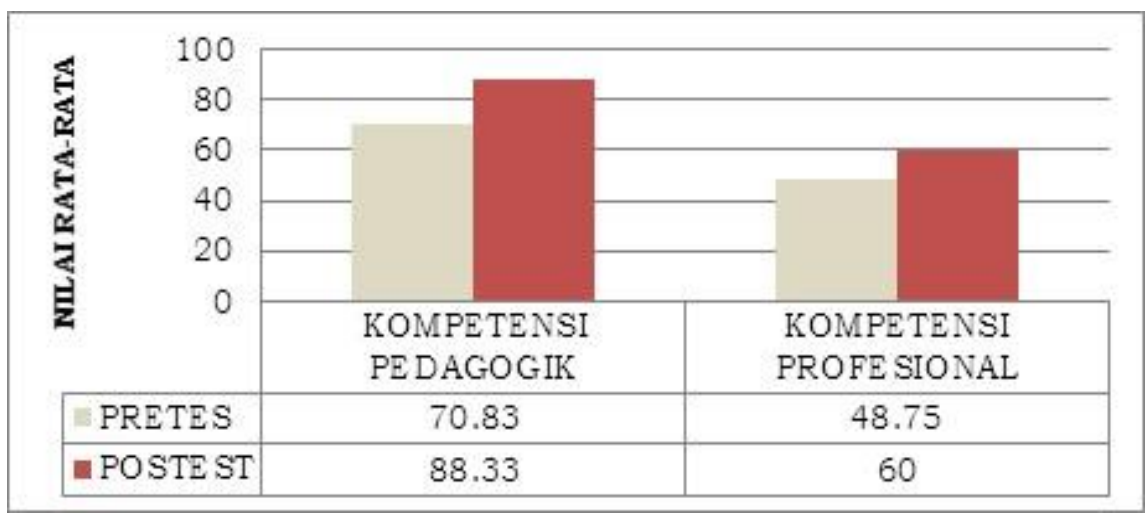

Gambar 3. Grafik Peningkatan Kompetensi Pedagogik dan Profesional Guru-Guru IPA Kabupaten Sijunjung

Jurnal Panrita Abdi, 2020, Volume 4, Issue 1. 
Gambar 3 menunjukkan bahwa nilai kompetensi pedagogik guru-guru IPA kabupaten Sijunjung sebelum diberikan kegiatan pendampingan (pretest) yaitu 70,83 dan setelah diberikan kegiatan pendampingan (posttest) memiliki nilai 88,33. Hal ini menunjukkan bahwa telah terjadi peningkatan pada kompetensi pedagogik guru-guru IPA. Selain itu, kompetensi profesional juga mengalami peningkatan dari nilai awal kompetensi profesional (pretest) yaitu 48.75 dan setelah diberikan pendampingan menjadi nilai sesudah (post test) menjadi 60. Peningkatan hasil kegiatan ini juga perlu dianalisis secara statistik dengan menggunakan rumus gain ternormalisasi. Hasil nilai gain ternormalisasi tersaji pada Tabel 3.

Tabel 3. Hasil analisis nilai gain ternormalisasi pada kompetensi pedagogik dan professional guru-guru IPA kabupaten Sijunjung

\begin{tabular}{lcc}
\hline Komponen & $<\mathrm{g}>$ & Interpretasi \\
\hline Kompetensi Pedagogik & 0,60 & Sedang \\
Kompetensi Profesional & 0,22 & Rendah \\
\hline
\end{tabular}

Tabel 3 menunjukkan bahwa nilai gain ternormalisasi kompetensi pedagogik guru-guru IPA kabupaten Sijunjung dalam pembelajaran prakarya pada kategori sedang. Peningkatan kompetensi pedagogik guru-guru IPA ini dapat diinterpretasikan sudah memuaskan. Sedangkan, nilai gain ternormalisasi kompetensi profesional guru-guru IPA kabupaten Sijunjung dalam pembelajaran prakarya berada pada kategori rendah. Hal ini menunjukkan bahwa peningkatan kompetensi profesional sudah cukup memuaskan. Grafik peningkatan kompetensi guru-guru IPA kabupaten Sijunjung secara keseluruhan terlihat pada Gambar 4.

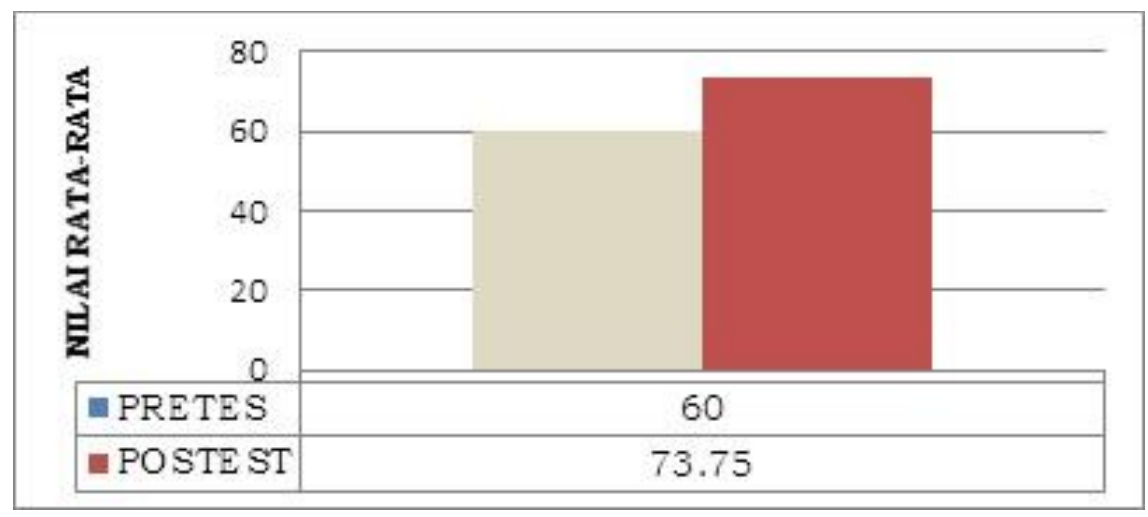

Gambar 4. Grafik Peningkatan Kompetensi dan Profesional Guru-Guru IPA Kabupaten Sijunjung

Gambar 4 menggambarkan bahwa telah terjadi peningkatan nilai rata-rata kompetensi guru-guru IPA dari 60 (pretest) menjadi 73,75 (posttest). Hasil analisis peningkatan kompetensi guru-guru IPA secara rata-rata juga perlu dianalisis dengan rumus gain ternormalisasi, dimana hasil nilai gain ternormalisasi terdapat Tabel 4.

Tabel 4. Hasil analisis nilai gain ternormalisasi pada kompetensi guru-guru IPA kabupaten Sijunjung

\begin{tabular}{lcc}
\hline Komponen & $<\mathrm{g}>$ & Interpretasi \\
\hline Kompetensi & 0,34 & Sedang \\
\hline
\end{tabular}

Tabel 4 menunjukkan bahwa kompetensi guru-guru IPA kabupaten Sijunjung dalam pembelajaran prakarya sudah memiliki nilai gain ternormalisasi pada kategori sedang atau peningkatan kompetensi sudah memuaskan. Peningkatan ini disebabkan pemberian pendampingan implementasi sains terapan dalam 
pembelajaran prakarya terutama yang berkaitan dengan aspek kerajinan budidaya, pengolahan yang dilaksanakan lengkap dengan demonstrasi dan praktiknya. Pelaksanaan kegiatan pengabdian dengan demonstrasi dan praktik langsung telah mampu meningkatkan 60\% pengetahuan dasar peserta (Dewi dkk., 2019).

\section{Kesimpulan}

Telah terjadi peningkatan kompetensi pedagogik guru-guru IPA kabupaten Sijunjung dalam pembelajaran prakarya dengan kategori sudah memuaskan. Sedangkan, peningkatan kompetensi profesionalnya sudah cukup memuaskan. Jadi, secara keseluruhan peningkatan kompetensi guru-guru IPA kabupaten Sijunjung dalam pembelajaran prakarya sudah memuaskan.

\section{Ucapan Terima Kasih}

Penulis mengucapkan terimakasih kepada Direktorat Riset dan Pengabdian Masyarakat (DRPM) Kemenristekdikti karena telah mendanai pengabdian skema program Kemitraan Masyarakat tahun 2019. Selain itu, ucapan terima kasih juga disampaikan kepada Rektor Universitas Negeri Padang (UNP), Ketua LP2M UNP, dan MGMP IPA SMP Kabupaten Sijunjung.

\section{Referensi}

Afrizon, R., \& Dwiridal, L. (2017). Upaya Menumbuhkan Karakter Peduli Lingkungan melalui Kajian Konsep Fisika Pada Arsitektur Kearifan Lokal Budaya Sumatera Barat. Jurnal Eksakta Pendidikan, 1(2): 9-16.

Dewi, P.S., \& Widiyawati, I. (2019). Penerapan Teknologi Budidaya Tanaman Obat sebagai Upaya Pemanfaatan Lahan Pekarangan di Kelurahan Pabuwaran, Purwokerto, Jawa Tengah. Jurnal Panrita Abdi, 3(2), 105 - 112.

Hake, R. (1998). Interactive-Engagement Versus Traditional Methods: a Six Thousand-Student Survey of Mechanics Test Data for Introductory Physics Courses". American Journal of Physics, 66 (1) : 64-74. American Association of Physics Teachers.

Kemendikbud. (2016). Model Silabus Mata Pelajaran Prakarya Sekolah Menengah Pertama/Madrasah Tsanawiyyah (SMP/MTs). Jakarta: Kementerian Pendidikan dan Kebudayaan.

Kudsiah, H., Tresnati, J., \& Ali , S. A. (2018). IbM Kelompok Usaha Bandeng Segar Tanpa Duri di Kabupaten Pangkep Sulawesi Selatan. Panrita Abdi Jurnal, 2(1), 55-63.

Paresti, S, Nuswantari, D. S. H., Yuliani, E., \& Samsudin, I. (2017). Buku Guru Prakarya untuk SMP/MTs Kelas VII. Jakarta: Pusat Kurikulum Kementerian Pendidikan dan Kebudayaan.

Puspasari, I., Triwidyastuti, Y., \& Harianto. (2018). Otomasi Sistem Hidroponik Wick Terintegrasi pada Pembibitan Tomat Ceri. Jurnal Nasional Teknik Elekto dan Teknologi Informasi (JNTETI), 7(1): 97-104.

Rifa'i, M.A., Kudsiah, H., \& Muzdalifah. (2017). Alih teknologi produksi benih anemon laut secara aseksual. Jurnal Panrita Abdi, 1(1), 33-39.

Rifa'i, M.A., Syahdan, M., Muzdalifah, \& Kudsiah, H. (2018). Pengembangan Usaha Produk Intelektual Kampus: Anemon Laut Ornamen. Jurnal Panrita Abdi, 2(1), 40-47.

Setiawati, E., \& Edwar, F. (2012). Teknologi Pengolahan Biodiesel dari Minyak Goreng Bekal dengan Teknik Mikrofiltrasi dan Transesterifikasi sebagai Alternatif Bahan Bakar Mesin Diesel. Jurnal Riset Industri, VI (2): 117-127. 


\section{Penulis:}

Renol Afrizon, Jurusan Fisika, Fakultas Matematika dan Ilmu Pengetahuan Alam, Universitas Negeri Padang, Padang. E-mail: afrizon@fmipa.unp.ac.id

Hidayati, Jurusan Fisika, Fakultas Matematika dan Ilmu Pengetahuan Alam, Universitas Negeri Padang, Padang. E-mail: hidayati@,fmipa.unp.ac.id

Relsas Yogica, Jurusan Biologi, Fakultas Matematika dan Ilmu Pengetahuan Alam, Universitas Negeri Padang, Padang. E-mail: relsas yogica@fmipa.unp.ac.id

Bagaimana men-sitasi artikel ini:

Afrizon, R., Hidayati, H., \& Yogica, R. (2020). Pendampingan Sains Terapan untuk Meningkatkan Kompetensi Guru-Guru IPA dalam Pembelajaran Prakarya di Kabupaten Sijunjung. Jurnal Panrita Abdi, 4 (1), 83 - 91. 